\title{
FASHIONS IN EARLY SYRIAC COLOPHONS
}

\author{
SEBASTIAN P. BROCK
}

UNIVERSITY OF OXFORD

\begin{abstract}
Syriac scribes were heirs to a long tradition in Mesopotamia of writing colophons. Although the content tended to be formulaic, nevertheless there was still considerable scope for individuality. Concentrating primarily on the evidence of fifth-and sixth-century colophons (but with occasional references to much later ones), seven specific aspects are considered: dating, prayer formulae, bumility formulae, expressions of relief at completion, warnings against illicit removal, verbosity, and historical notes.
\end{abstract}

Syriac scribes were heirs to a long tradition of writing colophons in Mesopotamia, ${ }^{1}$ and it is clear from the three Syriac legal documents from the early 240 s that they enjoyed a higher status in local society to that of their Greek counterparts, for it is only the Syriac scribes who give their name (following ancient Mesopotamian practice):

1 Cf. H. Hunger, Babylonische und assyrische Kolophone (AOAT 2; Neukirchen-Vluyn, 1968); for the constituent contents, see pp. 1-15; several features have remarkable parallels in some Syriac colophons, e.g. the phrase 'written and collated' (satir-ma bari) corresponds exactly to etketeb w-etpaḥham; some scribes wrote ana balat napšati-šu (e.g. Hunger, nos 157, 188 etc.), corresponding to 'for the life/salvation of his soul'. A detailed comparison would be worth undertaking (Hunger makes some brief comparisons with Greek, pp. 22-3). 
those who wrote out the contemporary Greek documents remain nameless.

Here our concern will be with literary manuscripts, for the most part dating from between the fifth to the seventh century, though here and there some attention will be paid to certain later colophons, including some contemporary examples. For the main period covered, some eighty-five colophons are available, sixtyseven of which are dated. ${ }^{2}$

At the end of a manuscript the scribe was no longer a servant of the text he is copying out, and he is finally free to express something of his individuality by choosing to provide his readers with a variety of different pieces of information. The most common items mentioned are:

- date of completion of writing (date of commencement as well is much rarer);

- place;

- person of who commissioned the manuscript, and/or its recipient;

- the scribe's own name, (ecclesiastical) rank; sometimes also the village of his origin;

- additional items.

Our interest here is focussed mainly on the last feature, but before turning to examples of these, brief mention should be given to the different modes of dating.

${ }^{2}$ A great deal of important data on the colophons of early Syriac manuscripts is to be found in the unpublished Oxford DPhil thesis by M. Mundell (Mango), Artistic Patronage in the Roman Diocese of the Oriens, 312$634 A D$ (1985); see also her 'Patrons and scribes indicated in Syriac manuscripts, 411-800 AD', Jabrbuch der Österreichischen byzantinischen Gesellschaft 32/4 (1982), pp. 3-12, and 'The production of Syriac manuscripts 400-700 AD', in G. Cavallo and others (eds), Scritture, Libri et Testi nelle aree provinciali di Bisanzio (Spoleto, 1992), pp. 161-79. In general see also my 'The art of the scribe', in The Hidden Pearl (Rome, 2001), II, pp. 243-62. 


\section{DATING $^{3}$}

The norm is provided by the Seleucid era, known either as that 'of Alexander' (anachronistically!), ${ }_{4}^{4}$ or 'of the Greeks'. In sixth-century dated manuscripts, the former is more common than the latter, but in later centuries, although 'of Alexander' remains quite common, the standard becomes 'of the Greeks'. ${ }^{5}$ From the late tenth century, perhaps as a result of the Byzantine reconquest of NW Syria, two different ways of expressing 'the blessed Greeks' begin to appear, yawnaye brike in the East Syriac tradition (first in 981, but then common only from the sixteenth century onwards), and yawnaye mbarke in the Syrian Orthodox and Melkite traditions (first in 998/9); the opposite, 'perfidious Greek' (yawnaye nkile) is found in a number of Syrian Orthodox manuscripts of the thirteenth century (and only rarely later): 6 the reason for this sudden outburst is not clear to me.

In the pre-Islamic period local eras (Antioch, Apameia, Bosra) and Indiction years are also occasionally found. Regnal years (the norm in Babylonian and Assyrian colophons) are confined to the Sasanian Empire. ${ }^{7}$ In the seventh century dating by the Hijra first

${ }^{3}$ For dating systems in general in Syriac manuscripts, see especially L. Bernhard, Die Chronologie der Syrer (Sitzungsberichte der Österr. Akad. der Wiss. 264; Wien, 1969), and F. Briquel-Chatonnet, 'Le temps du copiste: notations chronologiques dans les colophons de manuscrits syriaques', in F. Briquel-Chatonnet and H. Lozachmeur (eds), Proche Orient ancien: temps vécu, temps pensé (Paris 1998), pp. 177-210.

${ }^{4}$ Alexander died in 323 BC, while the Seleucid era (for Syriac scribes) began $1^{\text {st }}$ October 311 BC.

5 In both cases various extensions are found later on, such as 'Alexander, son of Philip', 'the blessed Greeks'; for details, see 'Perfidious Greeks, Blessed Greeks, Blessed Muslims, and the memory of Alexander in Dating formulae of Syriac manuscripts', in the Festschrift for M. Tamcke (ed. S. Grebenstein; forthcoming).

${ }^{6}$ For details, see 'Perfidious Greeks'.

7 Local eras: Vat. Syr. 160 (473; Antioch); Add. 14,571 (518; Apameia); Ad. 17,176 (532; Bosra); Indiction: Add. 14,445 (of 532), Vat. Syr. 143 (of 563), Add. 14,609 (of 586) and Wolfenbüttel (of 633); a few later examples are also to be found; regnal years: Add. 14,460 (of 599/600), and 14,471 (of 614/5). 
appears (alongside the Seleucid era) in 682 (Add. 14,666, a New Testament). ${ }^{8}$

\section{PRAYER FORMULAE}

The scribe very frequently requests the reader to pray for him (kull $d$-qare nsalle), and this will often be followed by some specific distinctive phraseology. A notable example to be found in ten out of the sample of eighty-five colophons from the fifth to seventh century makes reference to the repentant thief of Luke 23:

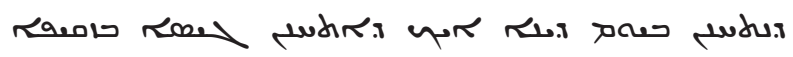

'let the reader pray that (the scribe) may be shown pity on the day of judgement just as the thief on the cross was shown pity'.

This features in a number of sixth-century manuscripts: Vatican Syr. 111 (Ephrem; dated Dec. 522); BL Add. 14,431 (Samuel; dated Apr. 545); Vatican Syr. 12 (Gospels; dated Jul. 548, Edessa); Florence Laur.Plut. I.56 (Gospels; dated Feb. 586, Monastery of John of Beth Zagba); BL Add. 17,152 (John Chrysostom; dated Dec. 593). It is also to be found in an early, undated manuscript, containing Eusebius' Ecclesiastical History, which may well also have been copied in Edessa.

Very often these prayer formulae ask 'may God ...', and here three recurring patterns predominate in the early colophons of our sample:

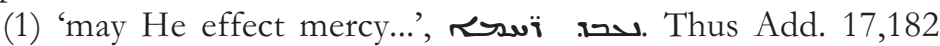
(of 474; Edessa), 12,156 (of 562), 14,559 (of 597/600; Palmyra region), 14,568 (of 599), 14,587 (of 603), 12,135 (of 611).

${ }^{8}$ For details of manuscripts using the Hijra era, see my 'The use of Hijra dating in Syriac manuscripts: a preliminary investigation', in J.J. van Ginkel, H.L. Murre-van den Berg, T.M. Lint (eds), Redefining Christian Identity. Cultural Interaction in the Middle East since the Rise of Islam (OLA 134; Louvain, 2005), pp. 275-290. For the structure of the dating formulae in early manuscripts and inscriptions, see my 'Dating formulae in Syriac inscriptions and manuscripts of the $5^{\text {th }}$ and $6^{\text {th }}$ centuries', in G.A. Kiraz and Z. Al-Salameen, From Ugarit to Nabataea. Studies in Honor of John F. Healey (Piscataway NJ, 2012), pp. 85-106, where certain features are singled out that seem to be connected with scribes with an Edessene connection. 
(2) 'may He hold worthy ...' Kafra d-Barta), 12,166 (of 553; Edessa), 14,558 (of 557), Vatican Syr. 143 (of 563; Mon. of John of Nerab), Vat. Syr. 104 (of 563/4; Barbaron), Add. 14,597 (of 569; Sarmin), Florence, Laur. Plut. I.56 (Beth Zagba), Add. 17,102 (of 599), 12,135 (of 611; Hina), 14,472 (of 624; Gedalta), Wolfenbüttel (Assfalg, nr.5; of 633; Beth Hala).

(3) 'may He give a reward/a good reward/a wage:

(a) with 'a reward' Vat. Syr. 142 (of 576; Sketis).

(b) with 'a good reward' r 597/600; near Palmyra), 14,458 (6 $6^{\text {th }} / 7^{\text {th }}$ cent.; the scribe's assistant is described as 'an Arab', suggesting that the manuscript came from the region under Ghassanid control). It is interesting to note that 'with a good wage' also features in an inscription dated 504, but whose provenance is unknown. ${ }^{9}$

(c) with 'a wage' $\sim$ in $~ r$ : thus Add. 14,425 (of 463/4; Amid); Add. 14,542 (of 509; the Monastery of P'NWR by a scribe from Amid); Add. 17,102 (of 599; original location erased); and Wolfenbüttel (of 633; Beth Hala).

\section{HUMILITY FORMULAE}

Formulae indicating the scribe's unworthiness already feature in the early colophons with the scribe describing himself as 'a sinner' ح (10 examples). After the seventh century humility formulae tended to become more and more expanded as time went on; a characteristic late example can be found in Berlin Or. quart. 580 (the text is printed in Sachau's Verzeichnis, nr. 45, p.169), a Qdam wad-Bathar copied in July 1850 in North-West Iran.

The scribe may sometimes state that out of humility he will not even give his name - but then does so, since he wishes for the reader's prayers. ${ }^{10}$ Alternatively, on occasion we find him giving his

9 R. Steiner, 'A Syriac church inscription from 504 CE', Journal of Semitic Studies 35 (1990), pp. 99-108.

${ }^{10}$ Thus also in the recent colophon of 1992, described below. 
name in cipher, either using alphabetical numerals, ${ }^{11}$ as Add. 14,603 (7th cent.), or the Alphabet of Bardaisan (thus the collator of Add.14,431, dated 545, and the scribe of Add.17,193, dated 874). Early readers might also disguise their identity in this way (e.g. early readers of Add. 17,176 of 532 and of Add. 14,448 dated 557). Although the alphabet of Bardaisan is only rarely used later on, a nineteenth-century example is provided by the West Syriac scribe of Add. 21,211 (Bar 'Ebroyo, Grammar), dated 1831.

\section{RELIEF AT COMPLETION}

It is not surprising that, at the end of his months-long (or even year-long) enterprise of copying a manuscript, the scribe should express his relief at the completion of his task. Among the various images used in this connection, one is particularly distinctive. In December 535, after he had finished copying out Genesis, the deacon Damianos wrote:

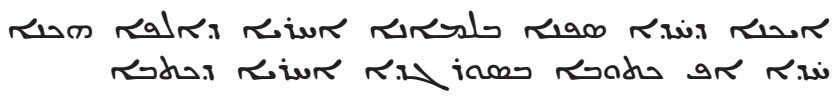

As the mariner (sappana) rejoices at his ship's final harbour, so too does the scribe rejoice at the last line.

Realizing, however, that he had to go on to Exodus, he wistfully added '(that is) if he is not beginning on another'! This happens to be the earliest known form of a very widely attested motif which is found in Greek and Latin colophons, as well as in Syriac. The earliest Latin example is from 669, while the Greek is not attested before 898. Syriac scribes adopted numerous variations and expansions, ${ }^{12}$ and a versified form came to be adopted by the

${ }^{11}$ For the use of these for quire numbering, very common after the $7^{\text {th }}$ cent., see my 'Les signatures en chiffres arithmétiques dans les manuscrits syriaques de la British Library', in F. Briquel-Chatonnet and M. Debié (eds), Sur les pas des Araméens chrétiens. Mélanges offerts à Alain Desreumaux (Paris, 2010), pp. 159-67.

12 See further my 'The scribe reaches harbour', Byzantinische Forschungen 21 (1995), pp. 195-202 (reprinted in From Ephrem to Romanos. Interactions between Greek and Syriac in Late Antiquity (Variorum Reprints, 1999), chapter XVI). See also now A.C. McCollum, 'The Rejoicing Sailor 
late Mor Julius Çiçek (d. 2005) at the end of the numerous texts that he copied (one of which is further mentioned below):

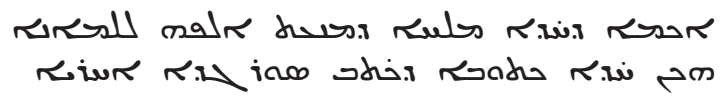

As the sailor rejoices / because his ship has reached harbour

so does the scribe rejoice / as he writes the last line.

Considerable liberty is found in the choice of wording; Damianos' sappana happens to be unique among the examples known to me, the normal terms being alpara, or qubernita, or mallaha. Other scribes preferred to speak just of the boat (elpa), without mention of the sailor.

As an example of the sort of elaboration that may be found I take the colophon of a Homiliary copied in 1015 in Hisn Patriq (Add. 12,165, of which Deir al-Surian Syr. Fragment 6 is part):

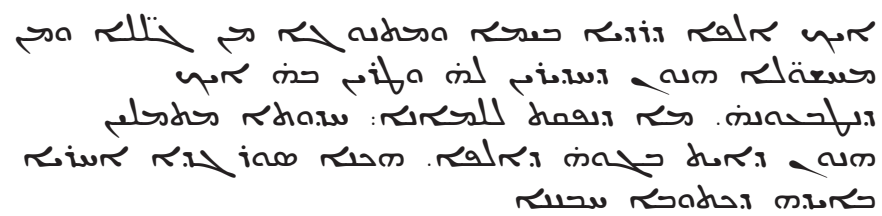

As a ship travelling on the sea, (nearly) wrecked by the waves and storms which surround and batter it so as to sink it, once it has left (the open sea) for the harbour, those who are on board the ship are filled with joy, so too with the last line at the hand of a lazy scribe.

Unusual phraseology can sometimes help point to connections between manuscripts. Thus the 'ship' colophon in Harvard Syr. 141 of 1201 opens 'In truth, experienced authors have said ...'

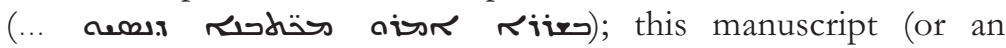
intermediary) was evidently known to scribes of several eighteenthand nineteenth-century manuscripts who pick it up and imitate it. ${ }^{13}$

and the Rotting Hand: Two formulas in Syriac and Arabic colophons', Hugoye 18:1 (2015), pp. 67-93 (esp. 67-85).

${ }_{13}$ Thus BL Or. 9632 (of 1898), substituting hurizir, as do a couple of eighteenth-century examples sold in recent years (Gospel Lectionary dated 1742, and Hudra dated 1733). 
A curious adaptation of this motif is to be found in an inscription in Qaraqosh, dated 1738, where it is used at the end of a long verse inscription describing the digging of a well: ${ }^{14}$

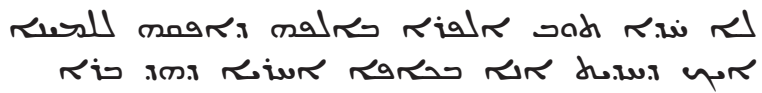

The sailor in his boat that he has brought to harbour does not rejoice more than I have rejoiced at the last stone of this well.

\section{BORROWERS BEWARE!}

Failure to return books is no modern phenomenon. Manuscripts might be borrowed for a variety of purposes: a colophon of 584 (Add. 12,160) mentions reading, collating and copying as possibilities why someone might want to borrow a manuscript. Already in our early sample we encounter several warnings, specifying penalties of one sort or another for borrowers who failed to return the manuscript. The most common phraseology used of the recalcitrant borrower is 'he who holds on to it' (ג), found in the following sixth-century manuscripts: Vatican Syr. 111 (of 522), Add. 12,160 (of 584), Florence Laur.Plut. I.56 (of 586), Add. 17,152 (of 593), and Add. 14599 (of 597/600). Only slightly less common is 'he who does not return it' (m) ras $\sim x$ ). Later scribes might combine the two: thus the scribe of BL Or. 8606 (dated 723) has 'he who holds on to it and does not return it to its owner'. A more heinous crime (from which all to many manuscripts have suffered) was the excision of folios: that this was already a problem in the sixth century is indicated by three scribes who give warnings against 'anyone who cuts something out' (ת) mentioned above (those dated 584, 586, and 593).

Various penalties are threatened against miscreants. A quite frequent one which starts to appear towards the end of the sixth century is based on Romans 2:22. The earliest example of this is in Add. 12,160, containing John Chrysostom on the Epistles, copied in 584 at the Monastery of Gubba Barraya by an 'Edessene scribe':

${ }_{14}$ Inscription AD.04.1 in A. Harrak, Recueil des inscriptions syriaques, t. 2, Iraq. Syriac and Garshuni Inscriptions (Paris, 2010), I, p. 269. 


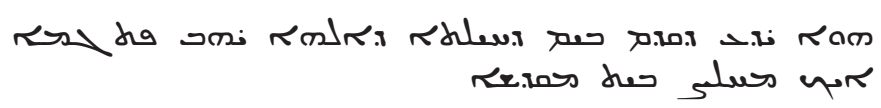

He will give answer before the fearsome tribunal of God like someone who plunders a sanctuary.

Two years later, in 586, the scribe of the 'Rabbula Gospels' employed the same wording, as did the 'Edessene scribe' who wrote Add. 17,152 (dated 593) and the scribe from among the exiled monks of the Monastery of the Orientals in Edessa who copied Add. 17,110. ${ }^{15}$

Other popular threats include the fate of certain biblical figures: the fate of Judas is first to be found threatened in Vatican Syr. 142, copied in Edessa in 576, while Gehazi's leprosy does not turn up until 899, when it features in the famous East Syriac 'massorah' manuscript, copied in Harran (Add. 12,138); for good measure the scribe adds 'and all the curses written in the Law'. Another potent threat is the 'anathema of the 318 Fathers' (that is, of the Council of Nicaea), which features first in a Melkite collection of Homilies copied in Edessa in 723 (BL Or. 8606).16 Interestingly, this is picked up by another Melkite scribe writing in Edessa a little over a century later, in $837,{ }^{17}$ who also adds the tag based on Romans 2:22.

15 The relevant sections of the three colophons are juxtaposed in my 'Manuscripts copied in Edessa', in P. Bruns and H.O. Luthe (eds), Orientalia Christiana. Festschrift für Hubert Kaufhold (Wiesbaden, 2013), p. 123.

It also features in Add. 14,478 (of 622) and 18,818 (seventh cent.).

16 For this manuscript, originally from Sinai, see P. Géhin, 'Manuscrits sinaïtiques dispersés III, Les fragments syriaques de Londres et de Birmingham', Oriens Christianus 94 (2010), pp. 16-19; the colophon was printed by R.W. Thomson, 'An eighth-century Melkite colophon from Edessa', Journal of Theological Studies ns 13 (1962), pp. 249-58.

17 The manuscript, containing Sahdona's Book of Perfection, and written for the Monastery of Mar Moses on Sinai, is now divided between a number of different libraries: see my 'New fragments of Sahdona's Book of Perfection at St Catherine's Monastery, Sinai', Orientalia Christiana Periodica 75 (2009), pp. 175-8, and P. Géhin, Manuscrits sinaïtiques dispersés, III', pp. 45-6.

The text of the colophon is printed in A. de Halleux, Martyrius (Sabdona), Oeuvres spirituelles (CSCO Scr. Syri 112, 1965), IV, pp. 92-3. 
That such threats against those who failed to return manuscripts were not always effective is well indicated in several notes in Deir al-Surian Syr. 30, where it is recorded that Patriarch Michael the Great (d.1199) - ignoring the anathema threatened by Abbot Mushe - borrowed a large quantity of manuscripts in order to have them copied at his own monastery of Barsauma, near Melitene, but failed to return them all. ${ }^{18}$

As time went on the threats became more dramatic and were sometimes added to manuscripts long after they had originally been copied. Thus in the early sixteenth century Severios, the Abbot of Deir al-Surian, took advantage of the visit, in 1516, of Metropolitan Gregorios of Jerusalem to get him to add lengthy anathemas to several manuscripts against anyone who removed a manuscript 'without the permission of the Abbot and the whole brotherhood', no matter whether he be a bishop, priest, any member of the clergy, or a layman. Thus a New Testament written in 1234 (Add. 17,124) was provided with the following: ${ }^{19}$

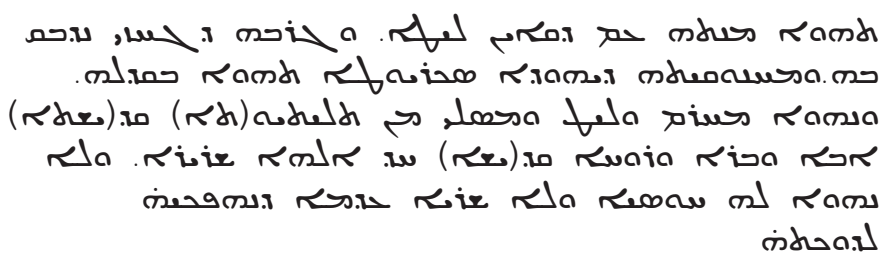

May his portion be with accursed Cain, may the leprosy of Gehazi adhere to him, my the rope that strangled Judas Iscariot be around his neck. He will be anathema, cursed and rejected by the Holy Trinity, Father, Son, and Holy Spirit, the one true God; and there shall be no forgiveness or release for him until he return it to its place.

${ }^{18}$ See S.P. Brock and L. van Rompay, Catalogue of the Syriac Manuscripts and Fragments in the Library of Deir al-Surian, Wadi al-Natrun (Egypt) (OLA 227, 2014), pp. xv-xvi, 228.

${ }^{19}$ Wright, Catalogue, p. 44. For another of Metropolitan Gregorios' added anathemas, see Deir al-Surian Syr. Fragment 85 (once attached to a Gospel manuscript). It is intriguing that both texts are introduced by $y$, which was later to become a frequent feature in East Syriac manuscripts (and then printed books). 


\section{VERBOSITY}

There was a strong tendency for scribes to grow increasingly verbose over the centuries, reaching a climax in the nineteenth century, especially among East Syriac scribes, who piled up long series of epithets for reigning bishops or abbots. A very early example, exceptional for its time, is to be found in a manuscript dated 535 containing the Acts of the Second Council of Ephesus, 449 (Add. 14,530; Wright, Catalogue, p.1029), where the abbot is described as:

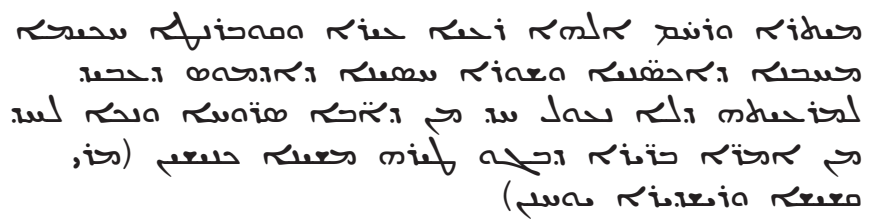

the excellent and God-loving wakeful shepherd, wise pilot, lover of strangers, mighty adamantine wall for his flock so that none of the ravaging wolves can enter and harm any of the simple lambs gathered in the peaceful sheepfold, (namely, the priest and abbot John).

We shall see an example of the longevity of a couple of these epithets in due course. One of the more curious titles given to bishops (and others) by late East Syriac scribes is 'cherub of flesh'

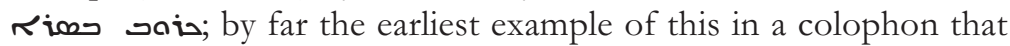
I have come across is the eleventh-century East Syriac manuscript containing the Second Part of the Discourses of Isaac of Nineveh (Oxford, Bodleian, Syr.e.7), copied in the Monastery of 'Abdisho' of Kom, in north Iraq; the phrase itself, however, can be traced back to Jacob of Serugh, who describes Joseph as a 'cherub of flesh' in one of his memre on the Nativity. 20

As Thomas Carlson has nicely illustrated elsewhere in this issue of Hugoye, later scribes tended to build up their colophons on the basis of a pool of stock phrases and formulae. Every now and then some enterprising scribe would introduce a new and distinctive feature which would then be imitated by others. An interesting example of this is to be found in a description of the Tigris as

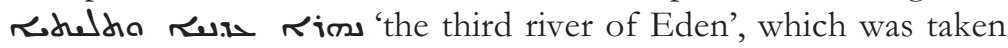

20 T. Kollamparampil, Jacob of Serugh's Homilies on the Nativity (Piscataway NJ, 2010), I, line 768. 
up by scribes working in towns situated on the river Tigris; thus we find examples from different locations over quite a span of time:

1586, Mansuriyeh (Cambridge Add. 1975)

1607, Cizre (Cambridge Add. 1981)

1826, Mosul (Cambridge Add. 1966)

Further examples will no doubt turn up in manuscripts digitized by the HMML project.

\section{HISTORICAL NOTICES}

Given the availability of space at the end of a manuscript, a scribe might, instead of indulging in lengthy accumulations of traditional phraseology, provide a note about some contemporary event or circumstances, thus providing the modern scholar with valuable historical information, sometimes not to be found elsewhere. ${ }^{21} \mathrm{~A}$ good example is provided by two manuscripts written in Jerusalem in 1138 (Lyon 1 and Paris Syr. 51), which give important details concerning the Syrian Orthodox community in the Holy City at that time..$^{22}$

It will be appropriate to conclude with three modern examples of such colophons, each one long and informative.

In 1987 the late Metropolitan Mor Julius Yeshu Çiçek published a photographic reproduction of a Gospel Lectionary that he had copied out earlier in the year. At the end, in the colophon, besides listing the manuscripts he used and the source for the illustrations (the thirteenth-century Gospel Lectionary of Bishop Dioscoros Theodoros), ${ }^{23}$ he provides the reader with two valuable sets of information, namely details of how long he took to copy the text, and a brief history of the Syrian Orthodox diaspora (golutho) in western Europe. ${ }^{24}$ It happens to be quite rare for scribes to indicate

${ }^{21}$ For some examples taken from Paris manuscripts, see F. BriquelChatonnet, 'Le temps du copiste', pp. 207-210.

${ }^{22}$ For a translation and study of these, see A.N. Palmer, 'History of the Syrian Orthodox in Jerusalem, Part II', Oriens Christianus 76 (1992), pp. 74-94.

${ }^{23}$ For this illuminated manuscript see now A. Kaplan, Le Lectionnaire de Dioscoros Theodoros (Mardin syr. 41/2). Calligraphie, ornamentation et iconographie (Bruxelles, 2013).

${ }_{24}$ Much of this valuable information is also to be found in his 'The Syrian Orthodox diaspora in Western Europe', Sobornost/Eastern Churches 
how long they took over copying a manuscript, ${ }^{25}$ so it is of particular interest to learn that Mor Julius began on $5^{\text {th }}$ January 1987 and ended on $4^{\text {th }}$ February, having spent not less than twelve hours each day writing, with a total of 340 hours; a further week was then spent on making corrections. His outline of the growth of the diaspora includes a list of all the bishops in office at the time, including those in India.

Since the final volume (VI) of George Kiraz's invaluable $A$ Computer-Generated Concordance to the Syriac New Testament (1992) contains the Appendix which is devoted to the prepositions, probably most users will not have occasion to refer to this volume - which is a pity, for at the end it contains a two-page colophon. In part the contents are traditional (though adapted to printing, giving the publisher's name): the reigning Patriarch is named, accompanied by various epithets, including 'friend of strangers' rasi, a nice example of continuity from the colophon of 535 quoted earlier. Prayers are requested for himself (with a fine array of traditional humility formulae) and his family. Helpers are mentioned, and the place of writing - the Cambridge college of Peterhouse. Readers are also asked to pray for the Head of the College, Henry Chadwick (d. 2008; the famous Patristic scholar, at that time Master of Peterhouse). Finally the date of completion, $5^{\text {th }}$ Nisan (April), with the comment 'in this year the rowers of Oxford University won in the rhaial Cambridge University on the river Thames in London'.

Four years later, 1996, saw the publication of George Kiraz's equally invaluable Comparative Edition of the Syriac Gospels. The colophon at the end of the fourth volume runs to five and a half pages. This commences with similar preliminary information, but with different phraseology (thus the Patriarch is described with a different epithet that is already found in the colophon of 535, namely 'wakeful shepherd' ri the departure 'from this wearisome and temporal life' of his father and of Metropolitan Mor Athanasius Samuel 'our metropolitan in the United States of America and Canada'. The colophon then goes

Review 28:2 (2006), pp. 19-27, and 'I cristiani siro-occidentali nella diaspora: l'emigrazione dei siro-aramaici nei secoli XVIII-XX', in E. Vergani and S. Chialà (eds), Le Chiese sire (Milan, 2005), pp. 41-48.

25 See Briquel-Chatonnet for examples in some Paris manuscripts, 'Le temps du scribe', p. 205. 
on to detail important information about the involvement of both his father and Mor Athanasius Samuel with the Dead Sea Scrolls in the early days after their discovery. Much of this information was new and had not been known to scholars at the time of publication; subsequently George Kiraz has made it available in much fuller and documented form in his book, Anton Kiraz's Archive on the Dead Sea Scrolls (2005). The colophon once again mentions the annual Boat Race between Oxford and Cambridge Universities, and we are told that 'in this year' (1995) it was Cambridge who won. The reader is also informed that in the same year the Syrian Orthodox Synod of Bishops divided the North American diocese into three. A final note, added subsequently, states that the author completed his Ph.D. dissertation in January 1996.

\section{IN CONCLUSION}

In this brief survey of some prominent features of dated colophons up to the mid seventh century, a number of forays have been made into more recent examples, indeed right up to our present time, in order to illustrate something of the remarkable continuity shown by colophons in their choice of phraseology. Returning now to the sample of early, and mostly dated, colophons, it is worth considering whether the combination of certain features might help identify local scribal schools. In an earlier study, of manuscripts written in Edessa, or by 'Edessene scribes', a few distinctive features were isolated, namely:

In the seven manuscripts copied in Edessa the city is regularly

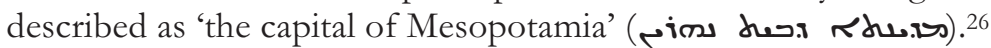

In a separate study, devoted to the dating formulae of sixthcentury inscriptions and manuscripts, another set of distinctive features were identified. ${ }^{27}$ In the early Syriac inscriptions and in the three legal documents of the early 240s, in conformity with practice in Nabataean, Palmyrene and Hatran inscriptions, the month regularly precedes mention of the year, but in the course of the sixth century the reverse, with the year coming first, becomes the

26 Add. 12,150 (of 411), Add. 17,182 (of 474), Deir al-Surian 10 (of 510), Vatican Syr. 140 (of 528), Add. 14,479 (of 533/4), Add. 17,107 (of 541), and Vatican Syr. 12 (of 548); cf. 'Manuscripts copied in Edessa'.

27 'Dating formulae'. 
norm; only a few manuscripts retain the older usage. The older sequence, month-year, features in two early Edessene manuscripts, Add. 12,150 (of 411), and Deir al-Syrian 10 (of 510);28 a variant of this, with inclusion of the day between the month and the year, features in four further manuscripts, two of which definitely have connections with Edessa, while the other two may possibly have been written there: St Petersburg 1 (of 462; very possibly written in Edessa), Add.14,445 (of 532; perhaps written in Edessa), Add. 12,160 (of 584; the scribe was from Edessa), and Add. 17,152 (of 593; copied by an 'Edessene scribe').

Drawing now on several of the features covered in the present study, one can observe certain recurrent combinations occurring, as will be apparent from table II below where, for the sake of brevity, manuscripts are identified by their dates rather than by their library numbers, for which see Table I. Two particular sets of recurring combinations emerge from Table II, and these are indicated by dates given in bold and in italic.

\section{TABLE I: SELECT DATED MANUSCRIPTS ${ }^{29}$}

For convenience the page number in Wright's Catalogue is given for manuscripts in the British Library.

\begin{tabular}{|c|c|c|c|}
\hline Date & Manuscript & $\begin{array}{l}\text { Hatch, } \\
\text { plate \# }\end{array}$ & Place of Writing \\
\hline $462 \mathrm{Apr}$ & St. Petersburg 1 & III & \\
\hline $463 / 4$ & $\begin{array}{l}\text { Add. } 14,425= \\
\text { Cat., } 5\end{array}$ & IV & Amid \\
\hline $510 \mathrm{Oct}$ & $\begin{array}{l}\text { Deir al-Surian } \\
\text { Syr. } 10\end{array}$ & & Edessa \\
\hline 512 & $\begin{array}{l}\text { Add. } 17,182= \\
\text { Cat., } 404\end{array}$ & IX & \\
\hline $522 \mathrm{Dec}$ & Vat. syr. 111 & XI & \\
\hline 535 May & $\begin{array}{l}\text { Add. } 14,530= \\
\text { Cat., } 1029\end{array}$ & XVIII & $\begin{array}{l}\text { Kafra d-Barta, Mon. of } \\
\text { Eusebius }\end{array}$ \\
\hline
\end{tabular}

28 A second archaism in these two manuscripts is the use of śnat without any preposition.

${ }^{29}$ For a complete list, see my 'A tentative check list of dates Syriac manuscripts up to 1300', Hugoye 15 (2011), pp. 19-46; also 'Dating formulae', pp. 92-4 (for the period covered here). 


\begin{tabular}{|c|c|c|c|}
\hline 541 & $\begin{array}{l}\text { Add. } 17,107= \\
\text { Cat., } 23\end{array}$ & XIX & Edessa \\
\hline 545 Apr & $\begin{array}{l}\text { Add. } 14,431= \\
\text { Cat., } 14\end{array}$ & & \\
\hline $548 \mathrm{Jul}$ & Vat. syr. 12 & $\mathrm{xX}$ & Edessa \\
\hline 5 & $\begin{array}{l}\text { Add. } 14,635= \\
\text { Cat., } 414\end{array}$ & & \\
\hline $557 \mathrm{Apr}$ & $\begin{array}{l}\text { Add. } 14,558= \\
\text { Cat., } 466\end{array}$ & XXIV & \\
\hline 562 & $\begin{array}{l}\text { Add. } 12,156= \\
\text { Cat., } 648\end{array}$ & & \\
\hline 563 Aug & Vat. syr. 143 & XXV & Mon. of John of Nerab \\
\hline 569 May & $\begin{array}{l}\text { Add. } 14,597= \\
\text { Cat., } 648\end{array}$ & XXX & $\begin{array}{l}\text { Sarmin, Mon. of John of } \\
\text { Nerab }\end{array}$ \\
\hline 576 & Vat. syr. 142 & & Sketis \\
\hline 581 Jun & $\begin{array}{l}\text { Add. } 17,169= \\
\text { Cat., } 543\end{array}$ & XXXI & \\
\hline $584 \mathrm{Jul}$ & $\begin{array}{l}\text { Add. } 12,160= \\
\text { Cat., } 472\end{array}$ & XXXIII & $\begin{array}{l}\text { Mon. of Gubba Barraya } \\
\text { (scribe from Edessa }\end{array}$ \\
\hline 586 & $\begin{array}{l}\text { Florence, } \\
\text { Laur.Plut.I.56 }\end{array}$ & XXXIV & $\begin{array}{l}\text { Mon. of John, B. Zagba } \\
\text { ('Rabbula Gospels') }\end{array}$ \\
\hline $593 \mathrm{Dec}$ & $\begin{array}{l}\text { Add. } 17,152= \\
\text { Cat., } 477\end{array}$ & XXXV & 'Edessene Scribe' \\
\hline $597 / 600$ & $\begin{array}{l}\text { Add. } 14,559= \\
\text { Cat., } 468\end{array}$ & & $\begin{array}{l}\text { Natpa d-Zagal, nr } \\
\text { Palmyra }\end{array}$ \\
\hline 599 & $\begin{array}{l}\text { Add. } 17,102= \\
\text { Cat., } 11\end{array}$ & XXXVI & \\
\hline 600 & $\begin{array}{l}\text { Add. } 17,110= \\
\text { Cat., } 118\end{array}$ & & $\begin{array}{l}\text { Mon. of Ramsha, exiles } \\
\text { from Mon. of Orientals, } \\
\text { Edessa }\end{array}$ \\
\hline $604 \mathrm{Jul}$ & $\begin{array}{l}\text { Add. } 12,170= \\
\text { Cat., } 458\end{array}$ & XXXVIII & Mathan, nr Bosra \\
\hline $611 \mathrm{Sep}$ & $\begin{array}{l}\text { Add. } 12,135= \\
\text { Cat., } 487\end{array}$ & & Mon. of Kawkba, Hina \\
\hline pre 618 & $\begin{array}{l}\text { Add. } 14,567= \\
\text { Cat., } 478\end{array}$ & & $\begin{array}{l}\text { Mon. of Qashir, mt } \\
\text { Sharda }\end{array}$ \\
\hline $621 / 2$ & $\begin{array}{l}\text { Add. } 14,478= \\
\text { Cat., } 91\end{array}$ & XLII & Haluga, nr Sarug \\
\hline 624 & $\begin{array}{l}\text { Add. } 14,472= \\
\text { Cat., } 82\end{array}$ & & Gedalta \\
\hline
\end{tabular}




$\begin{array}{lll}633 & \text { Wolfenbüttel } & \text { Bet Hala, Damascus } \\ \text { VII } & \text { Add. } 18,818= & \text { Mon Quryaqos, Tell } \\ & \text { Cat., } 471 & \text { Halfika }\end{array}$

TABLE II: SELECT RECURRENT FEATURES

Robber on Right:

522545548586593624

sam simta

510a 512548557563 569a 576 581a 584611

haw dmetul šmeh

535541548557562563576599604611633

ka'em 'al

$522584586593597 / 600611622$

la napne

522557576618622

yaheb petgama

$584593597 / 600$

mhalles

584586593600622

paseq menah

584586593

metul bubeh

584593

Mt 25 'Blessed'

510a 563/4 586611624

Mt 25 'Good servant'

576586599

The close links between 584, 586 and 593 have already been noted; Table II suggests that they also have looser links with 522, 557, 597/600, 611 and 622 (all indicated in bold). The other linked group (indicated in italic) consists of 548 (Edessa), 563, 576 and 599.

According to the great Assyriologist R. Borger, 1968 saw the birth of a new academic discipline of 'Kolophonologie'. ${ }^{00}$ It is to be hoped that Beth Mardutho's initiative in organising the present conference will ensure that colophonology will now have been provided with some solid foundations in Syriac studies as well.

30 In a review article of Hunger's volume, 'Bemerkungen zu den akkadischen Kolophonen', Die Welt des Orients 5 (1970), pp. 165-71, here p.165. 
